\title{
KESETIMBANGAN ADSORPSI ISOTERMIS LOGAM Cr (VI) PADA FLY ASH
}

\author{
Saripah sobah ${ }^{1 *}$, Fitria $^{1)}$, Yano Hurung Anoi ${ }^{2)}$, Diana $^{3)}$, dan Precast Octavianus ${ }^{3)}$

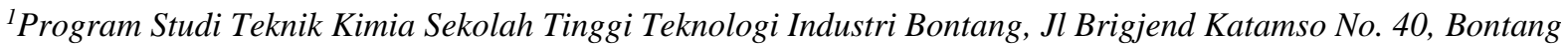 \\ ${ }^{2}$ Program Studi Teknik Mesin Sekolah Tinggi Teknologi Industri Bontang, Jl Brigjend Katamso No. 40, Bontang \\ ${ }^{3}$ Laboratorium P.T. Pupuk kalimatan Timur, Jl. James Simandjuntak No.1, Bontang \\ *Email: sobahbtg@gmail.com
}

\begin{abstract}
The Purpose of this study was to determine the optimum adsorption time of fly ash from the PT. Pupuk Kaltim in adsorbing Cr metal, optimal stirring speed, and optimal weight of fly ash under isothermic conditions in batches using the Langmuir equation has been carried out at atmospheric conditions, temperature $27^{\circ} \mathrm{C}$. Fly ash varies in weight and stirring speed. The filtrate was added with $2 \mathrm{~mL}$ of $0.1 \%$ $\mathrm{NH}_{4} \mathrm{Cl}$ after equilibrium, then analyzed using AAS AA-7000. The optimal adsorption time of fly ash in adsorbing $\mathrm{Cr}$ metal is 60 minutes. The optimal adsorption weight of fly ash is in $50 \mathrm{~mL}$ of $\mathrm{Cr}$ solution is 2 grams with an average efficiency value of $91.22 \%$. The optimum stirring speed of fly ash to adsorb $\mathrm{Cr}$ metal is $200 \mathrm{rpm}$.
\end{abstract}

Keywords: isothermic adsorption, fly ash, Cr metal

\section{PENDAHULUAN}

Penggunaan batubara di Indonesia terus meningkat dari tahun ke tahun. Rata-rata pemanfaatan dalam negeri tersebut terbesar diperuntukkan untuk kelistrikan yaitu $83 \%$ dan selebihnya untuk industri semen, pupuk, tekstil pulp, metalurgi, briket dan lainnya sebesar $17 \%$. Cadangan batubara diperkirakan akan habis dalam waktu 70 tahun bila tidak diimbangi dengan penemuan cadangan baru (Fitriana dkk., 2017)

Batubara menghasilkan limbah yang dapat mencemari lingkungan yaitu limbah gas seperti $\mathrm{CO}_{2}, \mathrm{NO}_{\mathrm{X}}, \mathrm{CO}, \mathrm{SO}_{2}$, hidrokarbon dan limbah padat. Limbah padat batubara berupa abu, yaitu abu terbang (fly ash) dan abu dasar atau bottom ash. Abu batubara mengandung logam beracun dalam konsentrasi yang jauh lebih tinggi apabila dilepaskan ke lingkungan oleh pembangkit listrik berbahan bakar batubara di Amerika ( Lokeshappa dan Dikshit 2012)

Produksi abu terbang di Indonesia ini terus meningkat, pada tahun 2000 jumlahnya mencapai 1,66 miliar ton dan mencapai 2 miliar ton pada 2006. PLTU Suralaya sebagai salah satu anak perusahaan dari PLN dan Independent Power Producer (IPP), menghasilkan limbah batubara sebesar 2,7 juta ton/tahun dan bisa terus bertambah hingga 11,2 juta ton/tahun pada 2027 (Thahir, 2017). Berdasarkan data Direktorat Jenderal Ketenagalistrikan KESDM pada tahun 2018, proyeksi kebutuhan batubara hingga 2027 sebesar 162 juta ton. Prediksi potensi FABA (Abu batu bara/fly ash) yang dihasilkan sebesar 16,2 juta ton, dengan asumsi $10 \%$ dari pemakaian batubara. (Damayanti, 2018)

Kromium dan senyawanya banyak digunakan pada beberapa industri seperti finishing logam, pewarna, pigmen, tinta, kaca, keramik, penyamakan, tekstil, pewarnaan dan pengawetan kayu dan lem. Logam kromium memberi dampak yang sangat buruk bagi lingkungan karena sifatnya yang sangat toxic dan terutama bagi kesehatan manusia (Lakherwal 2014). Menurut WHO, Cr (VI) adalah ion logam bersifat racun yang dapat menyebabkan gangguan sintesis DNA dan meningkatkan perubahan mutagen yang dapat menyebabkan tumor. Batasan maksimum air minum mengandung kromium sebesar $0,05 \mathrm{mg} / \mathrm{dm}$. Pada air tanah, ratarata kandungan kromium sebesar 0,07-2 mg/dm. Kromium akan terakumulasi di ginjal dan hati.

Teknik penyisihan logam yang bisa digunakan adalah presipitasi kimia, koagulasi-flokulasi, 
elektrokimia, oksidasi dengan ozon atau hidrogen peroksida, filtrasi membran, ion exchange, degradasi fotokatalitik, dan adsorpsi (Damayanti dkk, 2018). Adsorpsi banyak dikembangkan karena memiliki keunggulan seperti fleksibel dan sederhana, tidak sensitif terhadap polutan toksik, kebutuhan energi rendah, bisa menghasilkan efluen kualitas tinggi, serta biaya yang relatif murah (Ahmaruzzaman, 2011). Menurut Kan dkk, 2013 adsorpsi merupakan salah satu proses pengolahan air yang efektif dan sering digunakan untuk menghilangkan logam berat. Pemanfaatan fly ash sebagai adsorben telah banyak diteliti baik sebagai adsorben senyawa organik seperti Chlorophenols, o-xylene, phenol, toluene, minyak dan tar maupun senyawa anorganik seperti SOx, nitrat, Cd, Se, Rd, Sr, Zn, Ni, F, Nox, $\mathrm{Pb}, \mathrm{Hg}, \mathrm{Ba}, \mathrm{Co}, \mathrm{Cu} \mathrm{Ce}, \mathrm{Fe}$ dan amoniak (Ulku, 2010). Adsorpsi menggunakan Fly ash juga merupakan solusi biaya rendah untuk pengolahan air limbah tingkat lanjut (Visa, 2012)

Dalam penelitian ini fly ash yang digunakan adalah limbah yang berasal dari Boiler Batu Bara PT Pupuk Kaltim. Fly ash digunakan sebagai adsorben dalam menyisihkan logam berat Chromium yaitu $\mathrm{Cr}(\mathrm{VI})$. Kondisi optimum Penyerapan $\mathrm{Cr}$ oleh fly ash yang diteliti adalah variabel waktu kontak, berat fly Ash dan kecepatan pengadukan.

Model kesetimbangan adsorpsi yang digunakan untuk mempresentasikan data percobaan adsorpsi isoterm yang biasa digunakan adalah persamaan Langmuir yaitu:

$$
q=\frac{q_{\max } b C}{1+b C} \ldots \ldots \ldots \ldots \ldots \ldots \ldots \ldots \ldots
$$

dengan :

$q=$ jumlah senyawa $i$ terserap tiap satuan berat zeolit.

$q_{\max }=$ konstanta yang menyatakan jumlah luas permukaan adsorpsi yang telah tertentu dan tidak tergantung pada temperatur.

$b=$ konstanta kesetimbangan untuk senyawa $i$

$C=$ konsentrasi setimbang $i$ dalam fase larutan (Al Duri, 1995)

\section{METODE PENELITIAN}

\section{Bahan Penelitian}

Bahan-bahan yang digunakan pada penelitian ini adalah fly ash yang diperoleh dari Pabrik Boiler Batu Bara PT. Pupuk Kalimantan Timur, larutan $\mathrm{Cr}\left(\mathrm{NO}_{3}\right)_{3}$, larutan $\mathrm{NH}_{4} \mathrm{Cl} 0,1 \%$, larutan $\mathrm{HNO}_{3} 1$ $\%$, dan air demin yang diolah lagi menjadi bidest di laboratorium.

\section{Alat Penelitian}

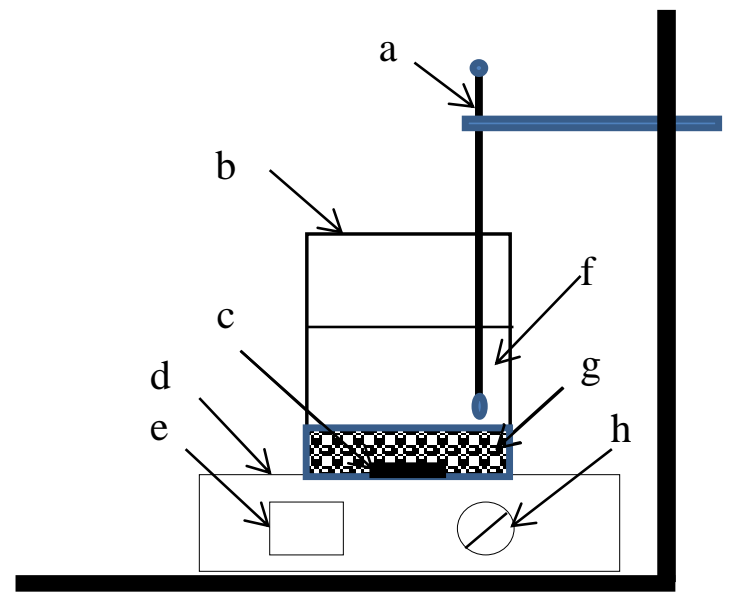

Gambar 1. Rangkaian Alat Adsorpsi Cr dengan fly $\underline{a s h}$

Keterangan gambar:
a. Termometer
e. Pengatur suhu
b. Gelas beaker $50 \mathrm{ml}$
f. Larutan
c. Stirer
g. Fly ash
d. Magnetik Stirer
h. Pengatur putaran

\section{Prosedur Penelitian}

Waktu kontak ditentukan dengan membuat larutan standar $\mathrm{Cr}$ dengan konsentrasi $8 \mathrm{mg} / \mathrm{L}$ sebanyak $250 \mathrm{~mL}$. Sebanyak 2 gram fly ash ditambahkan kedalam $50 \mathrm{~mL}$ larutan $\mathrm{Cr}$ lalu diaduk dengan menggunakan magnetik stirer pada kecepatan $150 \mathrm{rpm}$, masing-masing selama 30 menit, 60 menit, 90 menit dan 120 menit. Sebanyak $20 \mathrm{~mL}$ larutan disaring dan diambil filtratnya dan ditambahkan $2 \mathrm{~mL} \mathrm{NH}_{4} \mathrm{Cl} 0,1 \%$ di dalam tabung reaksi. Hasil dianalisis menggunakan AAS AA-7000

Variasi berat $\mathrm{Cr}$ yang digunakan adalah 2 $\mathrm{mg} / \mathrm{L}, \quad 4 \mathrm{mg} /, \quad 6 \mathrm{mg} / \mathrm{L}, \mathbf{8} \mathrm{mg} / \mathrm{L}$. Dan variasi kecepatan pengandukan yang digunakan adalah 150 rpm, $200 \mathrm{rpm}, 250 \mathrm{rpm}$ dan $300 \mathrm{rpm}$ 


\section{HASIL DAN PEMBAHASAN}

\section{Menentukan Waktu Kesetimbangan}

Waktu kontak penyerapan pada kondisi suhu $27^{\circ} \mathrm{C}$, berat fly ash 2 gram, kecepatan pengadukan $150 \mathrm{rpm}$, dan volume larutan $\mathrm{Cr} 50 \mathrm{~mL}$, disajikan pada gambar 1 .

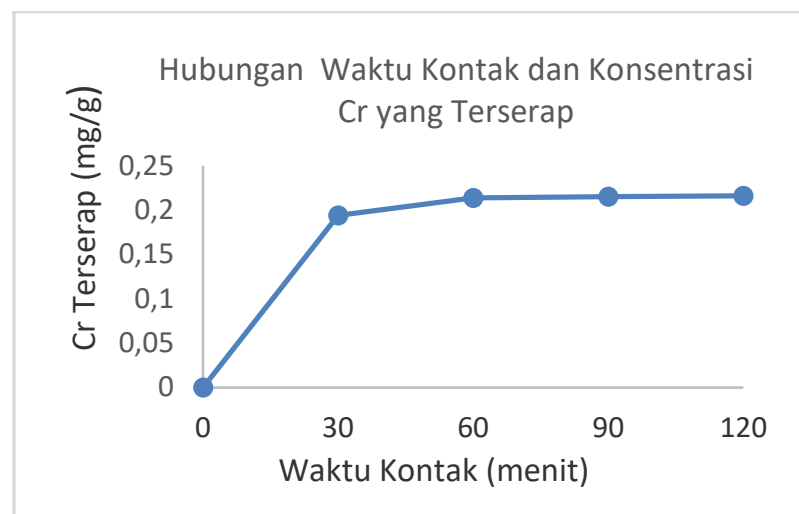

Gambar 1. Hubungan antara waktu kontak dengan Cr yang terserap

Kenaikan konsentrasi awal pada adsorpsi isotermis diikuti dengan meningkatnya jumlah zat yang teradsorpsi sehingga mencapai kesetimbangan. Adsorpsi Langmuir berasumsi bahwa pada permukaan adsorben terdapat sisi aktif yang sebanding dengan luas adsorben. Pada keadaan sisi aktif belum jenuh dengan adsorbat maka peningkatan konsentrasi adsorbat yang dipaparkan akan meningkat secara linear dengan jumlah adsorbat yang teradsorpsi (Oscik, 1982).

Hasil penelitian ini menunjukkan kemampuan menyerap logam $\mathrm{Cr}$ hingga terus meningkat hingga menit ke-60. Hal ini menunjukkan bahwa sisi aktif belum jenuh hingga menit ke 60. Pada rentang waktu kontak 60-120 menit, bertambahnya waktu kontak tidak diikuti dengan bertambahnya jumlah $\mathrm{Cr}$ terserap secara signifikan, Hal ini menunjukkan bahwa sisi aktif adsorben sudah mulai jenuh.

\section{Kecepatan Pengadukan Optimum Fly Ash dalam menyerap logam $\mathrm{Cr}$}

Kecepatan optimum fly ash dalam menyerap logam berat $\mathrm{Cr}$ pada kondisi suhu $27^{\circ} \mathrm{C}$, waktu 60 menit, dan volume larutan $\mathrm{Cr} 50 \mathrm{~mL}$, disajikan pada Tabel 1 .
Tabel 1. Pengaruh Kecepatan Pengadukan terhadap jumlah $\mathrm{Cr}$ yang terserap $\left(\mathrm{T}=27^{\circ} \mathrm{C}, \mathrm{t}=60\right.$ menit, $\mathrm{m}=1$ gram, $\mathrm{v}=50 \mathrm{~mL}$ )

\begin{tabular}{|c|c|c|c|c|}
\hline No & $\begin{array}{l}\text { Kons } \\
\text { awal } \\
\mathrm{mg} / \mathrm{L}\end{array}$ & $\begin{array}{c}\text { Kecepatan } \\
\text { pengadukan, } \\
\text { rpm }\end{array}$ & $\begin{array}{c}\mathrm{Cr} \\
\text { terserap } \\
\text { tiap } \\
\text { satuan } \\
\text { berat Fly } \\
\text { Ash, } \\
\mathrm{mg} / \mathrm{g}\end{array}$ & $\begin{array}{c}\mathrm{Cr} \\
\text { terserap } \\
\text { dengan } \\
\text { persamaan } \\
\text { Langmuir }\end{array}$ \\
\hline 1 & 2,144 & 100 & 0,012 & 0,012 \\
\hline 2 & 4,546 & 100 & 0,016 & 0,016 \\
\hline 3 & 6,647 & 100 & 0,025 & 0,025 \\
\hline 4 & 8,509 & 100 & 0,054 & 0,054 \\
\hline 5 & 2,144 & 150 & 0,015 & 0,015 \\
\hline 6 & 4,546 & 150 & 0,022 & 0,0220 \\
\hline 7 & 6,647 & 150 & 0,049 & 0,0490 \\
\hline 8 & 8,509 & 150 & 0,090 & 0,0900 \\
\hline 9 & 2,144 & 200 & 0,016 & 0,0160 \\
\hline 10 & 4,546 & 200 & 0,024 & 0,0240 \\
\hline 11 & 6,647 & 200 & 0,053 & 0,0530 \\
\hline 12 & 8,509 & 200 & 0,094 & 0,0940 \\
\hline 13 & 2,144 & 250 & 0,015 & 0,0490 \\
\hline 14 & 4,546 & 250 & 0,020 & 0,0910 \\
\hline 15 & 6,647 & 250 & 0,029 & 0,1400 \\
\hline 16 & 8,509 & 250 & 0,104 & 0,1930 \\
\hline 17 & 2,144 & 300 & 0,014 & 0,0140 \\
\hline 18 & 4,546 & 300 & 0,022 & 0,0220 \\
\hline 19 & 6,647 & 300 & 0,024 & 0,0240 \\
\hline 20 & 8,509 & 300 & 0,099 & 0,0990 \\
\hline
\end{tabular}

Pada Tabel 1. memperlihatkan bahwa jumlah $\mathrm{Cr}$ yang terserap optimum pada kecepatan pengadukan $200 \mathrm{rpm}$ yaitu sebesar $0,468 \mathrm{mg} / \mathrm{g}$. Kecepatan pengadukan menentukan kecepatan waktu kontak adsorben dan adsorbat. Pada kecepatan lambat, proses adsorpsi berlangsung lambat pula akan tetapi kecepatan pengadukan yang terlalu besar dapat menyebabkan rusaknya struktur adsorben sehingga proses adsorpsi kurang optimal (Mulyatna, 2003). Adsorbat yang telah menempel dan membentuk flok nantinya akan kembali pecah karena besarnya kecepatan pengadukan. 


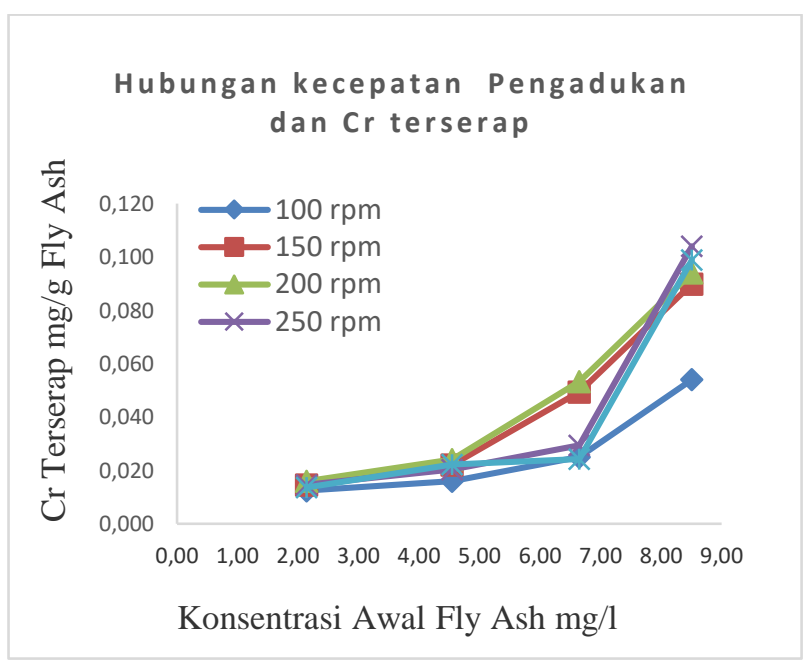

Gambar 2. Hubungan Kecepatam Pengadukan dan Jumlah Cr yang terserap

Tabel 2. Persamaan Isoterm pada kecepatan pengadukan $\left(\mathrm{T}=27^{\circ} \mathrm{C}, \mathrm{t}=60\right.$ menit, $\mathrm{m}=1$ gram, $\mathrm{v}=50 \mathrm{~mL}$ )

\begin{tabular}{|c|c|c|c|c|}
\hline \multirow[b]{2}{*}{ No } & \multirow{2}{*}{$\begin{array}{c}\text { Kecepatan } \\
\text { Pengadukan, } \\
\text { rpm }\end{array}$} & \multicolumn{2}{|c|}{$\begin{array}{c}\text { Tetapan } \\
\text { Persamaan Isoterm }\end{array}$} & \multirow[t]{2}{*}{$\begin{array}{c}\text { Ralat } \\
\text { rata- } \\
\text { rata, } \\
\%\end{array}$} \\
\hline & & $b_{1}$ & $q_{1}$ & \\
\hline 1 & 100 & 0,1019 & 0,0706 & 20,11 \\
\hline 2 & 150 & 0,0005 & 15,1515 & 26,02 \\
\hline 3 & 200 & $-0,0012$ & $-6,9930$ & 24,59 \\
\hline 4 & 250 & 0,0202 & 1,3396 & 9,91 \\
\hline 5 & 300 & 0,0792 & 0,1056 & 32,06 \\
\hline
\end{tabular}

\section{Berat Fly Ash optimum dalam menyerap logam $\mathrm{Cr}$}

Berat optimum fly ash dalam menyerap logam berat $\mathrm{Cr}$ pada kondisi suhu $27^{\circ} \mathrm{C}$, waktu 60 menit, kecepatan pengadukan $150 \mathrm{rpm}$, dan volume larutan Cr $50 \mathrm{~mL}$, disajikan pada tabel 4 .

Efisiensi meningkat dengan bertambahnya berat fly ash, akan tetapi jika dilihat dari efisiensinya, nilai optimum terjadi pada berat fly ash 2 gram, karena hampir mencapai 100\%. Jika penelitian ini harus dilanjutkan dengan meningkatkan berat fly ash, yakni 2,5 gram, 3 gram, 3,5 gram, 4 gram, dan seterusnya untuk konsentrasi $\mathrm{Cr} \quad 2 \mathrm{mg} / \mathrm{L}$ sampai dengan $8 \mathrm{mg} / \mathrm{L}$, maka pertambahan berat dan pertambahan nilai efisiensi tidak lebih besar dari $10 \%$.
Tabel 3. Efiseiensi jumlah $\mathrm{Cr}$ yang terserap dengan variasi berat $\mathrm{Cr}\left(\mathrm{T}=27^{\circ} \mathrm{C}, \mathrm{t}=60\right.$ menit, kecepatan pengadukan $=150 \mathrm{rpm}, \quad \mathrm{v}=50$ $\mathrm{mL}$ )

\begin{tabular}{cccc}
\hline No & $\begin{array}{c}\text { Berat } \\
\text { Flay Ash }\end{array}$ & $\begin{array}{c}\text { Cr terserap } \\
\text { tiap satuan } \\
\text { berat Fly } \\
\text { Ash, mg/g }\end{array}$ & $\begin{array}{c}\text { Efisiensi } \\
\text { Rata-rata } \\
(\%)\end{array}$ \\
\hline 1 & 0.5026 & 0.014 & \\
2 & 0.5027 & 0.016 & 4.75 \\
3 & 0.5025 & 0.026 & \\
4 & 0.5027 & 0.038 & \\
\hline 5 & 1.0026 & 0.014 & \\
6 & 1.0026 & 0.015 & 8.01 \\
7 & 1.0026 & 0.019 & \\
8 & 1.0026 & 0.023 & \\
\hline 9 & 1.5028 & 0.014 & \\
10 & 1.5027 & 0.042 & 31.03 \\
11 & 1.5027 & 0.080 & \\
12 & 1.5027 & 0.095 & \\
\hline 13 & 2.0027 & 0.049 & \\
14 & 2.0027 & 0.091 & 91.22 \\
15 & 2.0026 & 0.140 & \\
16 & 2.0028 & 0.193 & \\
\hline
\end{tabular}

Tabel 4. Persamaan Isoterm pada pengaruh berat $\mathrm{Cr}\left(\mathrm{T}=27^{\circ} \mathrm{C}, \quad \mathrm{t}=60\right.$ menit, kecepatan pengadukan $=150 \mathrm{rpm}, \mathrm{v}=50$ $\mathrm{mL}$ )

\begin{tabular}{ccccc}
\hline & & \multicolumn{2}{c}{ Tetapan } & Ralat rata- \\
& Berat Cr, & \multicolumn{2}{c}{ Persamaan Isoterm } & rata, \% \\
\cline { 3 - 4 } No & gram & $b_{1}$ & $q_{1}$ & \\
\hline 1 & 0,5 & 0,1466 & 0,0557 & 12,99 \\
2 & 1,0 & 0,4848 & 0,0257 & 7,17 \\
3 & 1,5 & $-0,0927$ & $-0,0557$ & 24,72 \\
4 & 2,0 & $-0,0118$ & $-1,8100$ & 1,79 \\
\hline
\end{tabular}

\section{KESIMPULAN}

1. Waktu Penyerapan Optimum fly ash dalam menyerap logam $\mathrm{Cr}$ adalah 60 menit

2. Kecepatan Pengadukan optimum fly ash dalam menyerap logam $\mathrm{Cr}$ adalah $200 \mathrm{rpm}$. 
3. Berat optimum penyerapan fly ash adalah pada $50 \mathrm{~mL}$ larutan $\mathrm{Cr}$ adalah 2 gram dengan rata-rata nilai efisiensi $91,22 \%$

\section{DAFTAR PUSTAKA}

Ahmaruzzaman, M., 2011, Industrial wastes as lowcost potential adsorbents for the treatment of wastewater laden with heavy metals, Colloid and Interface Science, 166, 36-59.

Al-Duri, B., 1995, A Review in Equiliberium in Single and Multicomponent Liquid Adsorption System, Review in Chemical Engineering, 11, p.p.101-143.

Damayanti, R., 2018, Coal Ash and Its Utilization: A Technical Review on Its Chemically Characteristics and Toxicology, Jurnal Teknologi Mineral dan Batubara Volume 14, Nomor 3, September 2018: $213-231$.

Damayanti,L., Notodarmodjo, S., Damanhurib, E., Penyisihan Logam $\mathrm{Cu}$ (II) dari larutan dengan Fly ash Batubara, Jurnal Neo Teknika Vol. 4 No 1, Juni 2018, hal. 30-38.

Fitriana, I., Anindhita, Sugiyono, A., Wahid, L. M. A. and Adiarso (eds.) (2017) Outlook energi Indonesia 2017: Inisiatif pengembangan teknologi energi bersih. Jakarta: Pusat Teknologi Sumber Daya Energi dan Industri Kimia.

Lakherwal, D, 2014., Adsorption of Heavy Metals, A Review, International Journal of Environmental Research and Development 4(1): 41-48.

Lokeshappa B and Dikshit, A. K. (2012) "Behaviour of metals in coal fly ash ponds," APCBEE Procedia, 1, pp. 34-39.

Mulyatna, L, dkk. 2003. Pemilihan Persamaan Adsorpsi Isoterm Pada Penentuan Kapasitas Adsorpsi Kulit Kacang Tanah Terhadap Zat Warna Remazol Golden Yellow 6. Jurnal Infomatek, Jurusan Teknik Lingkungan Fakultas Teknik: Universitas Pasundan.

Noll,K.E., Gaurnaris,V. and Hou, W.S.1992. Adsorption Technology for Air and Water Pollution Control. pp.1-8. Lewish Publisher Inc. Michigan.
Oscik, J. (1982) Adsorption, Ellis Harwood, Limited, England

Setiaka, Juniawan, Ita Ulfin, Nurul Widiastuti., 2011, Adsorpsi Ion Logam Cu dalam Larutan pada Abu Dasar Batubara Menggunakan Metode Kolom, Prosiding Tugas Akhir. Jurusan Kimia, Institut Teknologi Sepuluh Nopember. Surabaya.

Thahir, Z. A. (2017) Pemanfaatan fly ash dan bottom ash dari PLTU Suralaya Banten untuk pembuatan GEOPAV. Institut Teknologi Sepuluh Nopember.

Treybal, R.E., 1981, Mass Transfer Operatio, 3ed., pp. 565-567, McGraw-Hill, Inc., Kogakusha Ltd., Tokyo.

Ulku B.U., 2010., Fixation and stabilization of heavy metals in a product composed of fly ash and industrial acidic wastes, Tesis Jurusan Teknik Kimia, Institiut Teknologi Izmir.

Visa, M., 2012, Tailoring fly ash activated with bentonite as adsorbent for complex wastewater treatment, Applied Surface Science, Volume 263, Pages 753-762. 